\title{
Seedling age and nitrogen application affect on dry matter accumulation, partitioning and nutrient status of rice under temperate conditions
}

\author{
Rubia Rasool $^{1^{*}}$, Purshotam Singh, Sabia Akhter and Shazia Ramzan² \\ Division of Agronomy, S.K. University of Agricultural Sciences and Technology of Kashmir, Shalimar, Srinagar - \\ 191121, (Jammu \& Kashmir), INDIA \\ ${ }^{2}$ Division of Soil Science, S.K. University of Agricultural Sciences and Technology of Kashmir, Shalimar, Srinagar \\ -191121, (Jammu \& Kashmir), INDIA \\ *Department of Agronomy, Punjab Agricultural University, Ludhiana - 141004 (Punjab), INDIA \\ *Corresponding author. E-mail: rubiarasool@yahoo.com
}

Received: June 6, 2015; Revised received: February 19, 2016; Accepted: May 9, 2016

\begin{abstract}
Rice is the most important crop at the global level, as it used as a staple food in most of the countries of the world. Transplanting aged seedlings of paddy has a detrimental effect on the crop performance, which needs to be overcome for sustaining the productivity. Leaf colour chart based nitrogen application is an efficient and economical tool for enhancing the rice productivity and nitrogen use efficiency. With this in mind, a field experiment was conducted during kharif 2011, at the Research Farm of SKUAST-K, Shalimar, Srinagar (Kashmir) to optimize the seedling age of rice (Oryza sativa L.) under late transplanting conditions and to assess the suitability of using leaf colour chart as a nitrogen management tool to improve the performance of rice. The experiment was established in Randomized Block Design, with three replicates, 3 seedling ages and 6 nitrogen application treatments. The analyses of data revealed that 35 days old seedling recorded significantly higher total dry matter accumulation and dry matter partitioning to panicle $\left(8.2 \mathrm{t} \mathrm{ha}^{-1}\right)$ and leaf $\left(2.4 \mathrm{t} \mathrm{ha}^{-1}\right)$; grain yield $\left(7.4 \mathrm{t} \mathrm{ha}^{-1}\right) ; \mathrm{N}, \mathrm{P}$ and $\mathrm{K}$ uptake $(11.6,3.1$ and 11.3 $\mathrm{kg} \mathrm{ha}^{-1}$, respectively) $(\mathrm{p}<0.05)$. Among nitrogen application treatments significantly higher dry matter accumulation; yield $\left(8.6 \mathrm{t} \mathrm{ha}^{-1}\right)$ and $\mathrm{N}, \mathrm{P}$ and $\mathrm{K}$ uptake $\left(14.1,3.6\right.$ and $12.7 \mathrm{~kg} \mathrm{ha}^{-1}$, respectively) was found in $1 / 2 \mathrm{~N}$ as basal and remaining at LCC $<4 @ 20 \mathrm{~kg} \mathrm{ha}^{-1}(\mathrm{p}<0.05)$. Age of seedling and time of nitrogen application did not affect N, P, K and protein content of grain and straw significantly $(p>0.05)$. It is concluded that the yield of rice can be improved by transplanting 35-days old seedling under late transplanted conditions in temperate regions and by following LCC guided nitrogen management.
\end{abstract}

Keywords: Dry matter, Nitrogen, Phosphorus, Potassium, Rice and seedling age

\section{INTRODUCTION}

Rice is the staple food for more than $50 \%$ of world's population (Zhao et al., 2011), and thus holds the key to world food security (Dass and Chandra, 2013). The geometric growth of population and the arithmetic increase in rice production leave a vast gap in the food supply (Rajendran and Ganesa, 2014). The world demand for rice is projected to increase by $70 \%$ over the next 30 years (Patra and Haque, 2011) to maintain the present per capita supply, assuming the productivity of existing farmland does not decline. This demand can only be met by maintaining a steady increase in production by proper use of different factors of production. Among the various factors responsible for realizing potential yield of rice, age of seedlings at the time of transplanting and timely nutrition are the important non-monetary inputs, manipulation of which can lead to optimization of growth and yield.

Age of seedlings at transplanting is considered important for influencing grain yield in rice production systems, primarily by affecting dry matter accumulation and laying the foundation for determining the number of panicles at harvest (Rajendran and Ganesa, 2014). Transplanting seedlings at an appropriate age is of primary importance for uniform stand and seedling establishment, as "half of the success of rice cultivation depends upon the seedling" (Padalia, 1981). Constraints like scarcity of agricultural labour and non availability of inputs and financial constraints during peak periods of transplanting compel the farmers to resort to planting of aged seedlings (Rasool et al., 2015). Transplanting seedlings at a proper age can provide appropriate ground for achieving potential production by reducing the death of tillers and providing the optimum period for completion of growing cycle of paddy. When the seedlings are left for a longer period of time in the nursery, these are subjected to an increased competition within the nursery leading to exhaustion of intrinsic nutrients in the seedlings, which contributes to the poor performance of older seedlings after transplanting (Pasuquin et al., 2008).

Nitrogen, the key nutrient of rice production accounts 
for $67 \%$ of total nutrients applied to rice (Jayanthi et al., 2007). Although the nitrogen supply drives productivity, but the crop recovery of applied nitrogen is only 20 to $35 \%$ due to losses in several ways. The development and promotion of more efficient practices for nitrogen fertilizer management in rice consequently remain a high priority for increasing profitability of rice farming while protecting the environment (Buresh et al., 2004). Regulation of nitrogen supply to rice crop is dependent upon the interaction of a number of factors of which the timing of nitrogen application is usually most important. Application of nitrogen at proper time avoids periods of significant loss and provides adequate nitrogen when the crop needs it most. Synchronization between the crop nitrogen demand and supply from soil and applied fertilizer can be achieved by monitoring the plant nitrogen status (Cassman et al., 1994). Adopting need based variable rates of nitrogen application and using portable decision aids like LCC to improve nutrient management are the approaches to increase nitrogen use efficiency. LCC is a simple, easy-to-use and inexpensive (US\$1 a piece) diagnostic tool that can help farmers determine the right time of nitrogen application to rice crop by measuring leaf color intensity which is related to leaf $\mathrm{N}$ status (Alam et al., 2005). Whenever the leaf colour falls below the critical LCC value, a prescribed amount of nitrogen is applied which helps in maintaining the optimum concentration of leaf nitrogen. Keeping these facts in view, the present study was carried out to assess the effect of seedling age on dry matter accumulation and partitioning and nutrient status of rice under late transplanting conditions and to find the optimum time of nitrogen application to overcome the reduction in yield due to transplanting of aged seedlings.

\section{MATERIALS AND METHODS}

A field experiment was carried out at the Research Farm of SKUAST-Kashmir, Shalimar, Srinagar in kharif 2011. The site is situated $15 \mathrm{~km}$ towards the North of Srinagar $\left(34^{\circ} 05^{\prime} \mathrm{N}\right.$ latitude and $74^{\circ} 89^{\prime} \mathrm{E}$ longitude, $1587 \mathrm{~m}$ above mean sea level). Soil of the experimental field was silty clay loam, low in available nitrogen (253.6 kg ha $\left.{ }^{-1}\right)$, medium in available phosphorus $\left(14.3 \mathrm{~kg} \mathrm{ha}^{-1}\right)$, and medium in available potassium (248 $\mathrm{kg} \mathrm{ha}^{-1}$ ) with a $\mathrm{pH}=6.90$, electrical conductivity (EC) $=0.13 \mathrm{dSm}^{-1}$ and organic carbon $(\mathrm{OC})=0.52 \%$. The experiment was laid out in randomized complete block design with three replications having 18 treatment combinations including 3 levels of seedling age viz., 25,35 and 45 days old seedling and 6 levels of time of nitrogen application; control, recommended practice, $1 / 4 \mathrm{~N}$ as basal and $3 / 4$ in 3 equal splits at 14 days interval, $1 / 4 \mathrm{~N}$ as basal and $3 / 4$ in 2 equal splits at 14 days interval, $1 / 2$ $\mathrm{N}$ as basal and $1 / 2$ in 2 equal splits at 14 days interval, $1 / 2 \mathrm{~N}$ as basal and remaining at LCC $<4 @ 20 \mathrm{~kg} \mathrm{ha}^{-1}$ per application. Plot size was $4 \mathrm{~m} \times 3 \mathrm{~m}$ with a spacing of $15 \times 15 \mathrm{~cm}$. Diammonium phosphate (DAP) and muriate of potash (MOP) were applied as basal dose to each plot at the rate of $60 \mathrm{~kg} \mathrm{P}_{2} \mathrm{O}_{5} \mathrm{ha}^{-1}$ and $30 \mathrm{~kg} \mathrm{~K}_{2} \mathrm{O}$ $\mathrm{ha}^{-1}$, respectively before transplanting. Nitrogen was applied@120 kg ha ${ }^{-1}$ as per treatment in the form of urea. In case of LCC based treatments top dressing of urea was done only at LCC $<4 @ 20 \mathrm{~kg} \mathrm{ha}^{-1}$ application $^{-1}$. Transplanting of seedlings of all the three ages was done on $21^{\text {st }}$ June. Recommended cultural practices were followed for raising the crop. A sample of six randomly selected hills from penultimate row in each plot was collected at 15 days interval after transplanting till harvest. At 15, 30, 45 and 60 days after transplanting (DAT) the samples were sun dried for one day and then oven dried at 60 to $65{ }^{\circ} \mathrm{C}$ till constant weight reached. From 75 DAT onwards the plants were first separated into stem, leaf and panicle and then dried in the similar way as above. Dry weight of component fractions (stem, leaf and panicle) of six hills was determined. Total dry matter accumulation was obtained by adding weight of all the components of each plot. Both weights were then converted into $\mathrm{q} \mathrm{ha}^{-1}$. Yield was determined from net harvest area of $7.4 \mathrm{~m}^{2}$ after excluding border rows. Plant samples collected at harvest were sun dried followed by oven drying at 60 to $65{ }^{\circ} \mathrm{C}$ till a constant weight reached. Grain and straw samples were separately ground and used for chemical analyses. Nitrogen content was estimated by modified Kjeldhal method (Jackson, 1973) after digesting $0.5 \mathrm{~g}$ of plant sample (grain and straw) with $10 \mathrm{~mL}$ conc. sulphuric acid and digestion mixture. Phosphorus was estimated by Vanado-molybdo phosphoric yellow method using spectrophotometer after digestion of the samples in diacid mixture $\left(\mathrm{HNO}_{3}: \mathrm{HClO}_{4} ; 9: 4\right)$. Potassium was estimated by flame photometer after triple acid digestion of the samples. Nitrogen, phosphorus and potassium uptake was calculated by multiplying grain and straw yield by respective percentages of nitrogen, phosphorus and potassium and then expressed in $\mathrm{kg}$ ha 1 . Protein content in grain and straw was determined by multiplying nitrogen content of grain and straw by a factor 5.95 (Souza et al., 1999). Data were statistically analyzed by the method described by Cochran and Cox (1963). The significance of ' $F$ ' was tested at $5 \%$ probability.

\section{RESULTS AND DISCUSSION}

Dry matter accumulation: Dry matter accumulation reflects growth and metabolic efficiency of a plant, which ultimately influences the economic yield. Dry matter accumulation showed an increasing trend up from 15 days after transplanting up to harvest. 35 days and 25 days old seedling produced similar quantities of dry matter but were significantly superior to 45 days old seedling $(p<0.05)$ (Table 1$)$. Higher dry matter accumulation of 35 days old seedling under late transplanted conditions is attributed to the production of healthy plants. Mandal et al. (1984) also observed that successive delay in transplanting results in concomitant reduction in dry matter production of 25 days old seedling and longer stay of 45 days old seedling 
Table 1. Dry matter accumulation $\left(\mathrm{q} \mathrm{ha}^{-1}\right)$ as influenced by age of seedling and time of nitrogen application.

\begin{tabular}{|c|c|c|c|c|c|c|c|}
\hline Treatment & 15 DAT & 30 DAT & 45 DAT & $60 \mathrm{DAT}$ & 75 DAT & 90 DAT & At harvest \\
\hline \multicolumn{8}{|l|}{ Age of seedling (days) } \\
\hline 45 & 3.4 & 10.8 & 37.8 & 55.3 & 95.0 & 128.79 & 131.3 \\
\hline 35 & 4.1 & 15.6 & 46.2 & 59.7 & 102.8 & 150.70 & 158.4 \\
\hline 25 & 3.8 & 15.1 & 42.4 & 55.4 & 97.6 & 139.65 & 141.2 \\
\hline $\mathrm{CD}_{0.05}$ & 0.3 & 2.9 & 4.3 & 4.2 & 5.8 & 7.1 & 5.2 \\
\hline \multicolumn{8}{|l|}{ Time of nitrogen application } \\
\hline Control & 2.6 & 5.2 & 31.1 & 40.5 & 64.8 & 94.73 & 97.3 \\
\hline Recommended practice & 4.4 & 17.6 & 47.7 & 60.9 & 106.9 & 154.04 & 161.9 \\
\hline $\begin{array}{l}1 / 4 \text { basal; } 3 / 4 \text { in } 3 \text { equal splits at } \\
14 \text { day interval }\end{array}$ & 3.6 & 12.3 & 39.9 & 58.9 & 104.9 & 151.68 & 157.5 \\
\hline $\begin{array}{l}\mathrm{N}_{3}=1 / 4 \text { basal; } 3 / 4 \text { in } 2 \text { equal splits } \\
\text { at } 14 \text { day interval }\end{array}$ & 3.5 & 12.5 & 40.0 & 57.3 & 92.8 & 134.31 & 134.9 \\
\hline $\begin{array}{l}1 / 2 \text { basal; } 1 / 2 \text { in } 2 \text { equal splits at } 14 \\
\text { days interval }\end{array}$ & 4.4 & 18.4 & 47.9 & 57.5 & 96.6 & 137.03 & 138.8 \\
\hline $\begin{array}{l}1 / 2 \text { basal; remaining at } \mathrm{LCC}<4 \\
@ 20 \mathrm{~kg} \mathrm{ha}^{-1} \text { per application }\end{array}$ & 4.2 & 17.2 & 46.1 & 66.0 & 124.7 & 176.48 & 178.4 \\
\hline $\mathrm{CD}_{0.05}$ & 0.4 & 4.0 & 6.1 & 5.9 & 8.2 & 10.0 & 7.3 \\
\hline
\end{tabular}

DAT $=$ Days after transplanting

Table 2. Dry matter partitioning $\left(\mathrm{q} \mathrm{ha}^{-1}\right)$ as influenced by age of seedling and time of nitrogen application at 75,90 DAT and at harvest.

\begin{tabular}{|c|c|c|c|c|c|c|c|c|c|}
\hline \multirow[t]{2}{*}{ Treatment } & \multicolumn{2}{|c|}{$\begin{array}{l}\text { DMP at } 75 \\
\text { DAT }\end{array}$} & \multicolumn{4}{|c|}{ DMP at 90 DAT } & \multicolumn{3}{|c|}{$\begin{array}{l}\text { DMP at } \\
\text { harvest }\end{array}$} \\
\hline & $\begin{array}{l}\text { DAT } \\
\text { Leaf }\end{array}$ & Stem & Panicle & Leaf & Stem & Panicle & $\begin{array}{l}\text { harvest } \\
\text { Leaf }\end{array}$ & Stem & Panicle \\
\hline \multicolumn{10}{|l|}{ Age of seedling } \\
\hline 45 Days old seedling & 15.0 & 52.2 & 27.7 & 15.4 & 52.9 & 58.5 & 15.4 & 52.8 & 63.1 \\
\hline 35 Days old seedling & 21.4 & 49.1 & 32.3 & 23.9 & 50.7 & 76.2 & 23.9 & 50.6 & 82.9 \\
\hline 25 Days old seedling & 20.5 & 46.7 & 30.4 & 22.9 & 48.2 & 68.6 & 22.9 & 48.1 & 70.2 \\
\hline $\mathrm{CD}(\mathrm{p}=0.05)$ & 1.6 & 4.2 & 2.7 & 1.9 & 3.5 & 5.6 & 1.9 & 3.5 & 3.2 \\
\hline \multicolumn{10}{|l|}{ Time of nitrogen application } \\
\hline Control & 12.7 & 33.4 & 18.6 & 14.9 & 33.8 & 45.8 & 14.9 & 33.8 & 48.6 \\
\hline Recommended practice & 21.6 & 53.3 & 32.1 & 24.1 & 55.0 & 75.2 & 24.1 & 55.1 & 82.6 \\
\hline $\begin{array}{l}1 / 4 \text { basal and } 3 / 4 \text { in } 3 \text { equal splits at } \\
14 \text { days interval }\end{array}$ & 21.1 & 52.2 & 31.5 & 23.4 & 54.1 & 74.5 & 23.4 & 54.2 & 79.9 \\
\hline $\begin{array}{l}N_{3}=1 / 4 \text { basal and } 3 / 4 \text { in } 2 \text { equal splits at } \\
14 \text { days interval }\end{array}$ & 16.7 & 48.0 & 28.0 & 19.0 & 50.0 & 65.6 & 19.0 & 49.4 & 66.5 \\
\hline $\begin{array}{l}1 / 2 \text { basal and } 1 / 2 \text { in } 2 \text { equal splits at } 14 \\
\text { days interval }\end{array}$ & 16.9 & 49.6 & 30.2 & 19.3 & 51.2 & 65.8 & 19.3 & 51.4 & 68.1 \\
\hline $\begin{array}{l}1 / 2 \text { basal and remaining at LCC }<4 \\
\text { @ } 20 \mathrm{~kg} \mathrm{ha}^{-1} \text { per application }\end{array}$ & 24.7 & 59.5 & 40.5 & 27.4 & 61.3 & 87.6 & 27.4 & 61.3 & 92.6 \\
\hline $\mathrm{CD}(\mathrm{p}=0.05)$ & 2.2 & 6.0 & 3.8 & 2.7 & 5.0 & 7.9 & 2.7 & 4.9 & 4.5 \\
\hline
\end{tabular}

$\mathrm{DAT}=$ Days after transplanting, $\mathrm{DMP}=$ Dry matter partitioning

in the nursery affects seedling growth pattern in response to high seedling competition. Also the transplanting shock received during transplanting at advanced stage resulted in poor growth of 45 days old seedling, which might have hindered the dry weight accumulation. Depressed seedling vigour after transplanting due to the impairment of root growth in nursery has been reported earlier (Ros et al., 2003). Significantly higher dry matter production of paddy with 35 days old seedlings as compared to 25 and 45 days old seedlings has been previously reported by Padmaja and Reddy (1998). Sahoo and Rout (2004) reported that planting of four weeks old seedlings recorded greater shoot dry matter than that of five and six week old seedlings.

The nitrogen application as $1 / 2 \mathrm{~N}$ basal and remaining at LCC $<4 @ 20 \mathrm{~kg} \mathrm{ha}^{-1}$ application $^{-1}$ ), accumulated significantly higher quantity of dry matter from 75
DAT onwards than all other treatments $(p<0.05)$. Lowest quantity of dry matter was recorded in control (Table 1). This could be due to the fact that LCC guided nitrogen management provided specific amounts of nitrogen as per crop requirement throughout the growing season and reduced the leaching of nitrate $\left(\mathrm{NO}_{3}{ }^{-}\right)$in the soil. The result was the higher photosynthetic area, better interception of solar radiation and presence of photosynthetically active leaves for longer time. Jayanthi et al. (2007) reported significantly highest dry matter accumulation with nitrogen application in more number of splits (4 or 5) @ $20 \mathrm{~kg} \mathrm{~N} \mathrm{ha}^{-1}$ or $30 \mathrm{~kg} \mathrm{ha}^{-1}$ on the basis of LCC readings at weekly and bi-weekly interval.

Dry matter partitioning: The manner in which dry matter is distributed among different parts of the plant, determines the magnitude of economic yield. At 75 days after transplanting (DAT) most of the dry matter 
Table 3. N, P, K and protein content (\%) of grain and straw as influenced by age of seedling and time of nitrogen application.

\begin{tabular}{|c|c|c|c|c|c|c|c|c|}
\hline \multirow[t]{2}{*}{ Treatment } & \multicolumn{2}{|c|}{ N content } & \multicolumn{2}{|c|}{ P content } & \multicolumn{2}{|c|}{ K content } & \multicolumn{2}{|c|}{ Protein Content } \\
\hline & Grain & Straw & Grain & Straw & Grain & Straw & Grain & Straw \\
\hline \multicolumn{9}{|l|}{ Age of seedling } \\
\hline 45 Days old seedling & 1.019 & 0.461 & 0.204 & 0.171 & 0.346 & 1.00 & 6.06 & 2.79 \\
\hline 35 Days old seedling & 1.020 & 0.465 & 0.215 & 0.174 & 0.349 & 1.01 & 6.07 & 2.81 \\
\hline 25 Days old seedling & 1.10 & 0.479 & 0.219 & 0.175 & 0.349 & 1.03 & 6.55 & 2.89 \\
\hline $\mathrm{CD}(\mathrm{p}=0.05)$ & NS & NS & NS & NS & NS & NS & NS & NS \\
\hline \multicolumn{9}{|l|}{ Time of nitrogen application } \\
\hline Control & 0.993 & 0.461 & 0.203 & 0.169 & 0.345 & 1.00 & 5.91 & 2.74 \\
\hline Recommended practice & 1.066 & 0.473 & 0.217 & 0.176 & 0.349 & 1.018 & 6.34 & 2.82 \\
\hline $\begin{array}{l}1 / 4 \text { basal and } 3 / 4 \text { in } 3 \text { equal splits } \\
\text { at } 14 \text { days interval }\end{array}$ & 1.078 & 0.488 & 0.217 & 0.177 & 0.347 & 1.017 & 6.41 & 2.90 \\
\hline $\begin{array}{l}N_{3}=1 / 4 \text { basal and } 3 / 4 \text { in } 2 \text { equal } \\
\text { splits at } 14 \text { days interval }\end{array}$ & 1.029 & 0.471 & 0.216 & 0.173 & 0.350 & 1.019 & 6.12 & 2.80 \\
\hline $\begin{array}{l}1 / 2 \text { basal and } 1 / 2 \text { in } 2 \text { equal splits at } \\
14 \text { days interval }\end{array}$ & 1.014 & 0.471 & 0.212 & 0.169 & 0.350 & 1.031 & 6.03 & 2.80 \\
\hline $\begin{array}{l}1 / 2 \text { basal and remaining at } \mathrm{LCC}<4 \\
\text { @ } 20 \mathrm{~kg} \mathrm{ha}^{-1} \text { per application }\end{array}$ & 1.200 & 0.488 & 0.225 & 0.178 & 0.346 & 1.016 & 7.55 & 2.90 \\
\hline $\mathrm{CD}(\mathrm{p}=0.05)$ & NS & NS & NS & NS & NS & NS & NS & NS \\
\hline
\end{tabular}

Table 4. N, P, K uptake $\left(\mathrm{kg} \mathrm{ha}^{-1}\right)$ by grain and straw as influenced by age of seedling and time of nitrogen application.

\begin{tabular}{|c|c|c|c|c|c|c|}
\hline \multirow[t]{2}{*}{ Treatment } & \multicolumn{2}{|c|}{ N uptake } & \multicolumn{2}{|c|}{ P uptake } & \multicolumn{2}{|c|}{ K uptake } \\
\hline & Grain & Straw & Grain & Straw & Grain & Straw \\
\hline \multicolumn{7}{|l|}{ Age of seedling } \\
\hline 45 Days old seedling & 59.3 & 36.1 & 11.9 & 13.4 & 20.1 & 78.4 \\
\hline 35 Days old seedling & 75.7 & 40.6 & 15.9 & 15.2 & 25.9 & 88.3 \\
\hline 25 Days old seedling & 70.9 & 39.8 & 14.1 & 14.5 & 22.5 & 85.6 \\
\hline $\mathrm{CD}(\mathrm{p}=0.05)$ & 9.3 & 2.3 & 1.3 & 0.9 & 1.7 & 4.2 \\
\hline \multicolumn{7}{|l|}{ Time of nitrogen application } \\
\hline Control & 27.6 & 32.1 & 5.6 & 11.8 & 9.6 & 69.7 \\
\hline Recommended practice & 78.9 & 42.3 & 16.1 & 15.7 & 25.8 & 91.1 \\
\hline $\begin{array}{l}1 / 4 \text { basal and } 3 / 4 \text { in } 3 \text { equal splits at } 14 \\
\text { days interval }\end{array}$ & 78.1 & 42.1 & 15.7 & 15.2 & 25.1 & 87.7 \\
\hline $\begin{array}{l}N_{3}=1 / 4 \text { basal and } 3 / 4 \text { in } 2 \text { equal } \\
\text { splits at } 14 \text { days interval }\end{array}$ & 65.8 & 38.7 & 14.2 & 14.2 & 22.4 & 83.7 \\
\hline $\begin{array}{l}1 / 2 \text { basal and } 1 / 2 \text { in } 2 \text { equal splits at } \\
14 \text { days interval }\end{array}$ & 67.9 & 38.7 & 14.2 & 13.9 & 23.4 & 85.1 \\
\hline $\begin{array}{l}1 / 2 \text { basal and remaining at } \mathrm{LCC}<4 \\
@, 20 \mathrm{~kg} \mathrm{ha}^{-1} \text { per application }\end{array}$ & 95.4 & 46.8 & 19.5 & 17.1 & 30.1 & 97.4 \\
\hline $\mathrm{CD}(\mathrm{p}=0.05)$ & 13.1 & 3.2 & 1.9 & 1.2 & 2.4 & 5.9 \\
\hline
\end{tabular}

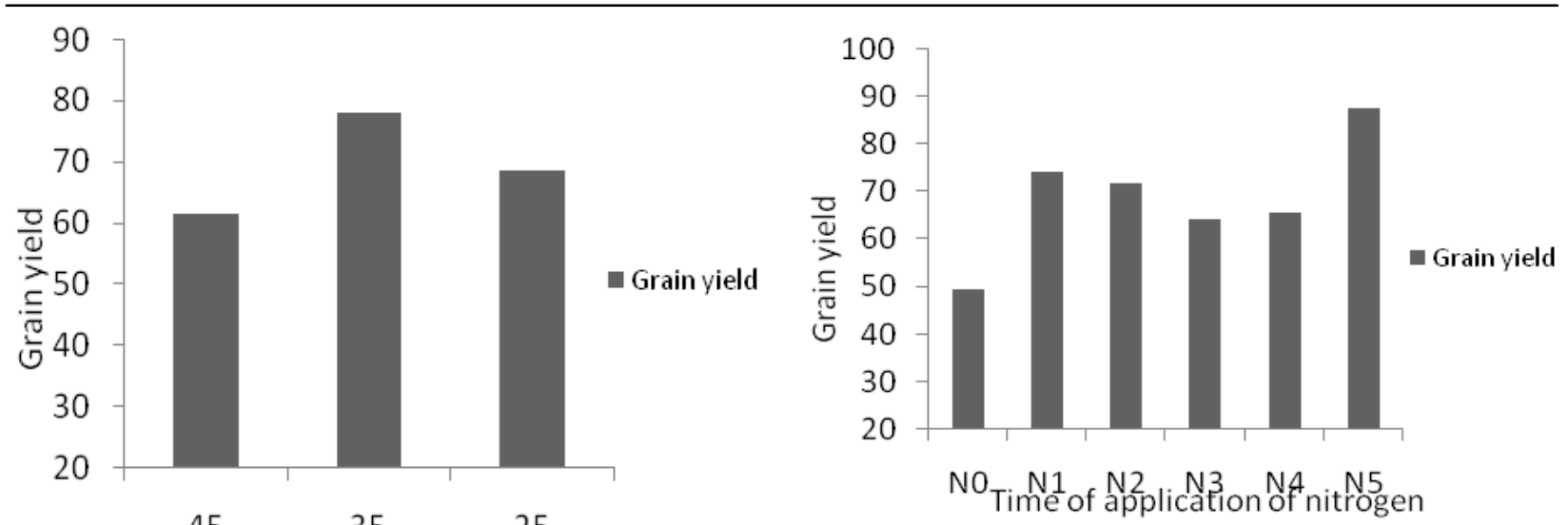

Fig. 2. Effect of time of nitrogen application on grain yield Fig. 1. Effect of age of seedling on grain yield $\left(q \mathrm{ha}^{-1}\right)$ $\left(q h a^{-1}\right)$.

$\mathrm{N}_{0}=$ Control, $\mathrm{N}_{1}=$ Recommended practice, $\mathrm{N}_{2}=1 / 4$ basal and $3 / 4$ in 3 equal splits at 14 days interval, $\mathrm{N}_{3}=1 / 4$ basal and $3 / 4$ in 2 equal splits at 14 days interval, $\mathrm{N}_{4}=1 / 2$ basal and $1 / 2$ in 2 equal splits at 14 days interval, $\mathrm{N}_{5}=1 / 2$ basal and remaining at LCC $<4$ @ $20 \mathrm{~kg} \mathrm{ha}^{-1}$ per application 
was partitioned to stem followed by leaf and panicle. At 90 DAT there was an increase in dry matter partitioning to panicle and was followed by stem and leaf. Similar trend was observed at harvest (Table 2). Increased dry matter partitioning to panicle is attributed to the fact that apart from accumulation of photosynthates in panicle (sink) resulting from flag leaf photosynthesis, mobile carbohydrates, proteins and mineral nutrients from other parts (stem, leaf etc.) also moved to panicle during the grain filling stage and the plant gradually became senescent. San-oh et al. (2004) also considered the effectiveness of assimilate remobilization from non -productive tillers towards reproductive ones. Thirty five days old seedling while remaining at par with 25 days old seedling recorded significantly higher quantity of dry matter in panicle and leaf as compared to 45 days old seedling $(p<0.05)$. As regards dry matter partitioning to stem, 45 and 35 days old seedling remained at par with each other and recorded significantly higher quantity of dry matter than 25 days old seedling $(p<0.05)$. Higher partitioning of dry matter to panicle of 35 days old seedling is due to the balance in partitioning of assimilates between the sink and source, owing to its better growth characters. Limited dry matter production caused by low photosynthetic rate and early senescence of leaves during grain filling period, or relatively low ratio of source to sink resulting in poor grain filling of rice has been studied previously (Lu et al., 1994; Yuan, 1994).

Among different nitrogen treatments, $\mathrm{N}_{5}(1 / 2 \mathrm{~N}$ as basal, remaining at LCC $<4 @ 20 \mathrm{~kg} \mathrm{ha}^{-1}$ application $^{-1}$ ) recorded higher dry matter partitioning to panicle. It may be due to the efficient translocation of photosynthates to sink, resulting from LCC guided nitrogen management. Higher nitrogen rates, primarily increased the chlorophyll concentration in leaves and thereby higher photosynthetic rate made plenty of photosynthates available during grain development (Mahzoor et al., 2006). Chowdhury et al. (2011) also observed the increase in mobilization of photosynthates to rice panicle at higher rate of nitrogen in comparison to lower rates of application.

Yield: Yield is an important component of the crop which reflects the resultant impact of all crop growth parameters that are affected by various input treatments. 35 days old seedling gave significantly more grain yield $\left(74.19 \mathrm{q} \mathrm{ha}^{-1}\right)$ and straw yield $(87.4 \mathrm{q}$ $\mathrm{ha}^{-1}$ ) than 25 days old seedling and 45 days old seedling $(\mathrm{p}<0.05)$ (Fig. 1). Bali et al. (1995) also found that planting five week old seedlings gave higher grain yield than seven week old seedling with $6.3 \%$ increase over the latter. Amin and Haque (2009) and Faghani et al. (2011) concluded that 35-days old seedling was better than those of relatively younger (15- and 25-day old) and older (45- day old) seedlings. In fact the healthy crop plants which had undergone normal physiological growth and field duration contributed to the higher yield of 35 days old seedling. Twenty-five days old seedlings were subjected to comparatively lower environmental elements in terms of temperature and sunshine hours which hindered them to exploit their potential. While as, Rajesh and Thanunathan (2003) attributed the reduction in yield with planting of older seedlings (50 days old seedling) to minimum dry matter production in these seedlings compared to 30 days old seedling.

Regarding nitrogen application treatments, $\mathrm{N}_{5} \quad(1 / 2$ basal, remaining at LCC $<4 @ 20 \mathrm{~kg} \mathrm{ha}^{-1}$ application $^{-1}$ ) recorded highest grain yield $\left(86.69 \mathrm{q} \mathrm{ha}^{-1}\right)$ and $\mathrm{N}_{\mathrm{o}}$ (control) resulted in lowest yield $(\mathrm{p}<0.05)$ (Fig. 2). This is attributed to the fact that crop performance depends not only on the absolute amount of nitrogen but also upon the nitrogen supply pattern and uptake process at each growth stage for respective yield components. Leaf colour chart based fractional application of nitrogen (synchronizing with the crop demand) was effective in maintaining optimal leaf nitrogen during critical stages of plant growth, which led to conducive translocation of higher amounts of carbohydrates to the sink. The critical LCC value of 4 with 25 and $35 \mathrm{~kg} \mathrm{~N} \mathrm{ha}^{-1}$ was found to be suitable for guiding nitrogen application to achieve the highest grain yield by Houshmandfar and Kimaro (2011).

Nutrient and protein content: Nitrogen and phosphorus content of grain was higher than that of straw but the trend was reverse for potassium content. Age of seedling and time of nitrogen application could not make any significant difference in nutrient and protein content of grain and straw ( $>0.05)$ (Table 3$)$. This is attributed to the fact, that uptake of nutrients is accompanied by increase in growth (biomass production) of plant. Thus the increased absorption of nutrients well buffered by increased dry matter production failed to show any significant change in nutrient content of grain and straw. Dingkuhn et al., (1991a, b) reported that the production of high leaf area led to low foliage nitrogen concentration because of nitrogen dilution. Since protein content is obtained by multiplying nitrogen content by a constant factor, 5.95 for rice (Souza et al., 1999), therefore it couldn't show any significant difference due to age of seedling and time of application of nitrogen $(p>0.05)$.

Nutrient uptake: Age of seedling created significant variation in $\mathrm{N}, \mathrm{P}$ and $\mathrm{K}$ uptake by grain and straw. 35 days old seedling registered the highest $\mathrm{N}(75.67 \mathrm{~kg}$ ha $\left.{ }^{-1}\right), \mathrm{P}\left(15.92 \mathrm{~kg} \mathrm{ha}^{-1}\right)$ and $\mathrm{K}\left(25.89 \mathrm{~kg} \mathrm{ha}^{-1}\right)$ uptake in grain followed by 25 days old seedling $(p<0.05)$. N, P, $\mathrm{K}$ uptake was also highest in straw of 35 days old seedling which was at par with 25 days old seedling (Table 4). This is attributed to higher yield of 35 days old seedling compared to other two ages of seedling. Regarding time of application of nitrogen, $\mathrm{N}_{5}(1 / 2$ basal, remaining at LCC $<4 @ 20 \mathrm{~kg} \mathrm{ha}^{-1}$ application $^{-1}$ ), showed highest nutrient uptake, other treatments except $\mathrm{N}_{0}$ (control) remained at par $(\mathrm{p}<0.05)$ (Table 4). This is because of the fact that additional supply of nitrogen during maximum growth phase favors higher nitrogen uptake of the crop. Increased stimulation of phosphorous 
and potassium uptake by nitrogen was due to specific influence of nitrogen on the physiological activity of the roots that control nutrient absorption and transfer into the symplast. Houshmandfar and Kimaro (2011) found that total nitrogen uptake was higher for LCC based nitrogen treatments than for fixed schedule recommended nitrogen application. Nitrogen uptake in grain and straw increased with increment of nitrogen levels up to $100 \mathrm{~kg} / \mathrm{ha}$ (Mannan et al., 2010).

\section{Conclusion}

It was concluded that transplanting aged seedlings lead to a poor crop performance. Maintaining of optimum leaf nitrogen status through LCC guided nitrogen management helps in supplying photosynthates in adequate quantities for proper crop growth and development. Thus, the yield of rice can be improved by transplanting 35-day old seedlings under late transplanted conditions and by following LCC guided nitrogen management.

\section{REFERENCES}

Alam, M.Z., Ahead, M., Alam, M.S., Haque, M.E. and Hossien, M.S. (2005). Performance of seedling age and seedling raising techniques in yield and yield components of transplanted aman rice. Pakistan Journal of Biological Sciences, 5: 513-516.

Amin, A.K.M.K. and Haque, M.A. (2009). Seedling age influence rice (Oryza sativa L.) performance. Philippine Journal of Science, 138(2): 219-226.

Bali, A.S., Singh, K.N., Balli, A.S., Ganai, B.A. and Hasan, B. (1995). Effect of transplanting date, number and age of seedling on rice (Oryza sativa). Indian Journal of Agronomy, 40 (3):504-507.

Buresh R, Peng S, Huang J, Yang J, Wang G, Zhong X, Zou $Y$ (2004). Rice systems in China with high nitrogen inputs, pp. 143-153. In Mosier et al. (eds) Agriculture and the nitrogen cycle: Assessing the impacts of fertilizer use on food production and the environment. Island Press, Washington DC, USA, p. 296.

Cassman, K.G., Kropff, M.J. and Yan, Z.D. (1994). A conceptual frame-work for nitrogen management of irrigated rice in high-yield environments In: Viramani S.S. (Ed.), Hybrid Rice Technology: New Developments and Future Prospects, IRRI, Los Banos, Philippines, pp:81-96.

Chowdhury, S.R., Brahmanand, P.S., Kumar, A., Kundu, D.K. and Behera, M.S. (2011). Growth and yield of over -aged rice (Oryza sativa L.) seedlings under different nitrogen levels in waterlogged conditions. Indian Journal of Agricultural Sciences, 81(12): 1149-1152.

Cochran, J.C. and Cox, M.M. (1963). Experimental Designs. Asia Publishing House, Bombay, pp. 293-316.

Dass, A. and Chandra, S. (2013). Irrigation, spacing and cultivar effects on net photosynthetic rate, dry matter partitioning and productivity of rice under system of rice intensification in Mollisols of northern India. Experimental Agriculture 49(4):504-523.

Dingkuhn, M., Schnier, H.F., De Datta, S.K., Dorffling, K., Javellana, C. (1991a). Relationships between ripeningphase productivity and crop duration, canopy photosynthesis and senescence in transplanted and direct-seeded lowland rice. Field Crops Research, 26, 327-345.
Dingkuhn, M., Penning de Vries, F.W.T., De Datta, S.K., van Laar, H.H. (1991b). Concepts for new plant type for direct seeded flooded tropical rice. In: Direct Seeded Flooded Rice in the Tropics, International Rice Research Institute, Los Baños, Philippines, pp. 17-38.

Faghani, R., Mobasser, H.R., Dehpor, A.A. and Kochaksarai, S.T. (2011). The effect of planting date and seedling age on yield and yield components of rice (Oryza sativa L.) varieties in North of Iran. African Journal of Agricultural Research, 6(11): 2571-2575.

Houshmandfar, A and Kimaro, A. (2011). Calibrating the leaf color chart for rice nitrogen management in Northern Iran. African Journal of Agricultural Research 6(11): 2627-2633.

Jackson, M.L. (1973). Soil chemical analysis. Prentice Hall of India, New Delhi, India. p. 498.

Jayanthi, T., Gali, S.K., Angadi, V.V. and Chimmads, V.P. (2007). Effect of leaf colour chart based nitrogen management on growth and yield parameters of rainfed rice. Karnataka Journal of Agricultural Sciences, 20(2): 272-275.

Lu, X., Zhang, Z. and Virmani, S. S. (1994). Breeding status quo of two- line system hybrid rice. Chinese Journal of Rice Science, 8:48-54.

Mahzoor, Z., Ali, R.I., Awan, T.H., Khalid, N. and Ahmad, M. (2006). Appropriate time of nitrogen application to fine rice. Journal of Agricultural Research, 44(4): 36-42.

Mandal, B.K., Sainik, T.R. and Ray, P.K. (1984). Effect of age of seedling and level of nitrogen on the productivity of rice. Oryza, 21: 225-232.

Mannan, M.A., Bhuiya, M.S.U., Hossain, H.M.A. and Akhand, M.I.M. (2010). Optimization of nitrogen rate for aromatic basmati rice (Oriza sativa L.). Bangladesh Journal of Agricultural Research, 35(1): 157-165.

Padalia, C.R. (1981). Effect of age of seedling on the growth and yield of transplanted rice. Oryza, 18: 165-167.

Padmaja, K. and Reddy, B.B. (1998). Effect of seeding density in nursery, age of seedlings and crop geometry on growth and yield of hybrid rice during wet season. Oryza, 35: 380-381.

Patra, P.S. and Haque, S. (2011). Effect of seedling age on tillering pattern and yield of rice (Oryza sativa L.) under system of rice intensification. ARPN Journal of Agricultural and Biological Science, 6(11): 33-35.

Pasuquin, E., Lafarge, T., Tubana, B. (2008).Transplanting young seedlings in irrigated rice fields: Early and high tiller production enhanced grain yield. Field Crops Research, 105: 141-155.

Rajendran, K. and Ganesa, R. V. (2014). Effect of age of seedlings on growth and yield of rice. Indian Journal of Advances in Plant Research, 1(5): 62-66.

Rajesh, V. and Thanunathan, K. (2003).Effect of seedling age, number and spacing on yield and nutrient uptake of traditional Kambanchamba rice. Madras Agricultural Journal, 90 (1-3): 47-49.

Rasool, R., Singh, P. and Akhter, S. (2015). Growth, yield attributes and yield of rice (oryza sativa 1.) as affected by age of seedling and time of nitrogen application under temperate conditions. Indian Journal of Ecology, 42(1): 143-147.

Ros C., Bell, R. W. and White, P. F. (2003). Seedling vigour and the early growth of transplanted rice (Oryza sativa). Plant and Soil, 252: 325-337.

Sahoo, N.C. and Rout, L. (2004). Effect of seedling age and plant density on growth, yield and nutrient uptake in 
high yielding rice varieties and hybrids. Indian Journal of Agronomy, 49 (1):72-75.

San-oh, Y., Mano, Y., Ookawa, T., Hirasawa, T. (2004). Comparison of dry matter production and associated characteristics between direct-sown and transplanted rice plants in a submerged paddy field and relationships to planting patterns. Field Crop Research, 87: 43-58.

Souza, S.R., Stark, E.M.L.M. and Fernandes, M.S. (1999). Foliar spraying of rice with nitrogen : effect on protein levels, protein fractions and grain weight. Journal of
Plant Nutrition, 22(3): 579-588.

Yuan, L.P. 1994. Increasing yield potential in rice by exploitation of heterosis. p. 1-6. In S.S. Virmani (ed.) Hybrid rice technology, new developments and future prospects. International Rice Research Institute, Los Ban os, Laguna, The Philippines.

Zhao, L, Wu, L., Wu, M., and Li, Y. (2011). Nutrient uptake and water use efficiency as affected by modified rice cultivation methods with irrigation. Paddy Water Environment, 9: 25-32. 